\title{
Soft chemical synthesis and characterization of BaWO4 nanoparticles for photocatalytic removal of Rhodamine B present in water sample
}

\author{
M. Mohamed Jaffer Sadiq • A. Samson Nesaraj
}

Received: 15 August 2014/ Accepted: 11 October 2014/Published online: 22 October 2014

(C) The Author(s) 2014. This article is published with open access at Springerlink.com

\begin{abstract}
In recent years, the use of metal oxides as photocatalysts for degradation of organic substances has attracted the attention of the scientific community. Metal oxide nanoparticles have been studied due to their novel optical, electronic, magnetic, thermal and potential applications as catalysts, gas sensors, photo-electronic devices, etc. In this research work, we report a simple, soft chemical route for synthesizing $\mathrm{BaWO}_{4}$ nanoparticles using cheap chemicals such as barium nitrate (precursor salt) and sodium tungstate (precipitating agent). The final product was dried at room temperature overnight and calcined at $400{ }^{\circ} \mathrm{C}$ and $800{ }^{\circ} \mathrm{C}$ for $2 \mathrm{~h}$ to get phase-pure product. The prepared nanoparticles (as prepared and heat-treated samples) were characterized by X-ray powder diffraction, Fourier transform infrared spectroscopy, scanning electron microscopy, energy dispersive X-ray analysis and UV-Vis spectroscopy techniques. Photocatalytic degradation characteristics of Rhodamine $\mathrm{B}$ in water using $\mathrm{BaWO}_{4}$ nanoparticles were studied and reported.
\end{abstract}

Keywords $\mathrm{BaWO}_{4}$ nanoparticles $\cdot$ Soft chemical method · Characterization · Photocatalytic studies

\footnotetext{
M. Mohamed Jaffer Sadiq

Department of Nanosciences and Technology, School of Science and Humanities, Karunya University, Karunya Nagar,

Coimbatore 641 114, India
}

A. Samson Nesaraj $(\bowtie)$

Department of Chemistry, School of Science and Humanities, Karunya University, Karunya Nagar, Coimbatore 641 114, India e-mail: drsamson@karunya.edu

\section{Background}

Water pollution is one of the worldwide problems nowadays and this can directly affect the health of living organisms. Because of the industrialization, effluents from most of the industries are discharged directly or indirectly into water sources without treating the harmful or dangerous compounds present in it and this may lead to water pollution. There are wide varieties of water pollutants available, which include waste chemicals, waste organic matter, presence of harmful pathogens, etc. Water pollution is a burning global problem; hence development of suitable eco-friendly treatment procedures is a mandatory requirement at present [1]. One of the most harmful pollutants present in industrial waste water is organic dyes. Organic dyes are used for various industrial applications such as paper, leather, cosmetics, drugs, electronics, plastics, textiles, etc. From among these, it was reported that the textile industry alone utilizes $80 \%$ of the synthetic dyes for printing purpose [2]. Most of the dyes have non-biodegradable compounds [3]. Recently, researchers have developed methods for the treatment of waste water especially for the removal of dyes using techniques based on chemical, physical and biological means [4]. However, these treatment methods are not suitable for large scale due to their high cost. Therefore, alternative treatment methods, which are financially viable and green-chemical in nature, are required by the industrial sectors. Photocatalysis technology is one of the best water treatment technologies, since it is an economically viable and environment-friendly technique for the purification of waste water; it removes all kinds of organic and inorganic pollutants and contaminants present in waste water [5].

Barium tungstate (BaWO4) is the heaviest member of the family of the alkaline earth tungstates. Like many other 
$\mathrm{ABX}_{4}$ type compounds, $\mathrm{BaWO}_{4}$ crystallizes at ambient conditions in the tetragonal scheelite-type structure (space group [SG]: $141 / a$, No. $88, Z=4$ ) [6]. $\mathrm{BaWO}_{4}$ is extensively investigated because of its good electrical conductivity, magnetic and photoluminescence properties [7]. As one of the most reactive alkaline earth tungstates, $\mathrm{BaWO}_{4}$ based materials play an important role in wide variety of technological applications as light emitting diodes [8], humidity sensors [9], optic filters [10], scintillator detectors [11], photocatalysts [12], microwave dielectrics [13], phosphors [14] and solid state lasers [15]. Recently, many studies have been reported on the preparation and characterization of metal tungstates using various preparation methods such as Czochralski process [16], precipitation method [17], hydrothermal synthesis [18], solid-state reaction [19], pulsed laser deposition method [20], electrochemical process [21], molten salt synthesis [22], polymeric precursor method [23], solvothermal synthesis [24], sonochemical route [25] and DNA-templated synthesis [26].

It was found that, Rhodamine B is a most important basic dye of the xanthene class. It is highly water soluble and is widely used as a colorant in textile industry, food stuffs and is a well-known water tracer fluorescent. It is harmful to human beings and animals, and causes irritation of the skin, eyes and respiratory tract. The carcinogenicity, reproductive and developmental toxicity, neurotoxicity and chronic toxicity of Rhodamine B toward humans and animals have been experimentally proven. Also, it was found that Rhodamine B cannot be effectively removed by biological treatment processes due to the slow kinetics reaction [27].

The first part of this research work has been focused on the synthesis of $\mathrm{BaWO}_{4}$ nanoparticles by simple soft chemical route and systematic characterization of these materials in order to explore their structural, microstructural, elemental, chemical and surface properties. The second part has been dealt with the study of photocatalytic properties of $\mathrm{BaWO}_{4}$ to degrade organic dye (Rhodamine B) present in water under UV-light irradiation. The obtained results are discussed and presented in this research article.

\section{Experimental}

\section{Materials}

The analytical grade chemicals such as Barium Nitrate (99.8 \% purity, Merck, India), Sodium Tungstate $(99.0 \%$ purity, Merck, India), Rhodamine B ( $>95.0 \%$ purity, Sigma-Aldrich, India) and Ethanol (99.0 \% purity, Merck, India) were used in this study. These materials were used as

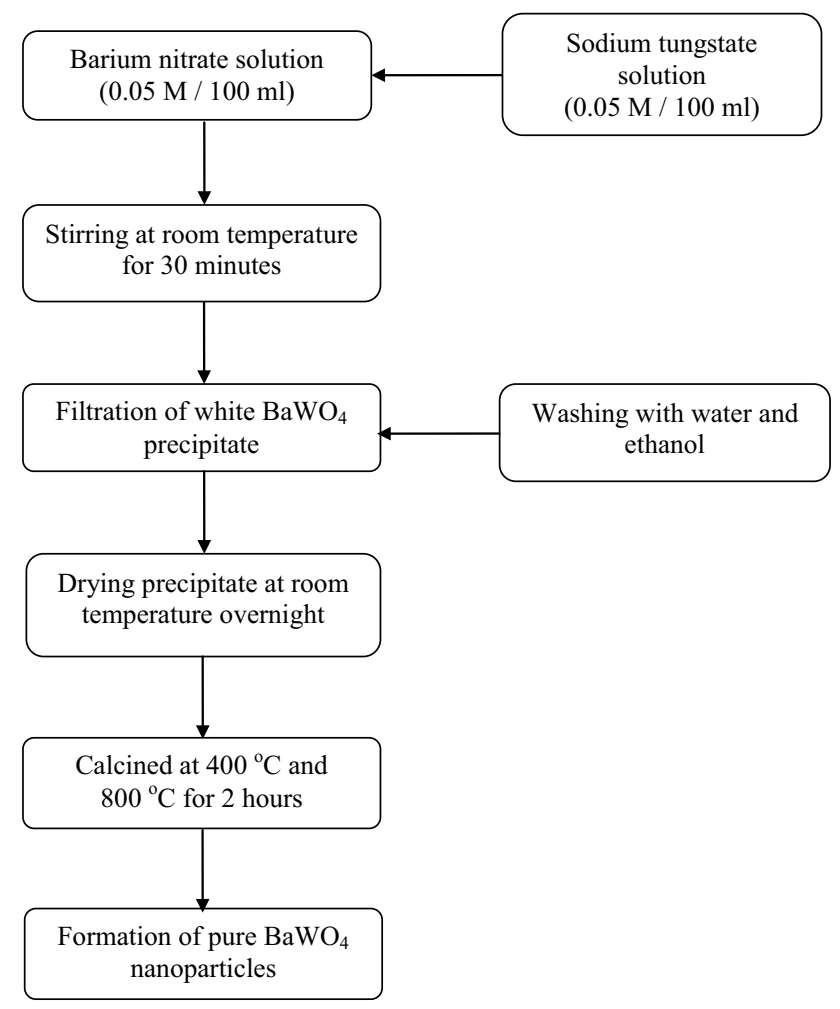

Fig. 1 Flow chart to prepare $\mathrm{BaWO}_{4}$ nanoparticles by simple soft chemical route

received without any further purification. All reactions were carried out with deionized water.

Preparation of $\mathrm{BaWO}_{4}$ nanoparticles

The $\mathrm{BaWO}_{4}$ nanoparticles were by simple soft chemical route as follows: Barium nitrate $\left(\mathrm{Ba}\left(\mathrm{NO}_{3}\right)_{2}\right)$ and sodium tungstate $\left(\mathrm{Na}_{2} \mathrm{WO}_{4} \cdot 2 \mathrm{H}_{2} \mathrm{O}\right)$ aqueous solutions were prepared with desired molar ratio. They were mixed together and stirred well for about $30 \mathrm{~min}$ in a magnetic stirring apparatus at room temperature. The obtained precipitate was filtered and washed thoroughly with (1:9) ethanol/ distilled water mixture several times to remove the byproducts. Finally, the precipitate was dried at room temperature overnight. The dried particles were calcined at $400{ }^{\circ} \mathrm{C}$ and $800{ }^{\circ} \mathrm{C}$ for $2 \mathrm{~h}$ each to check the phase purity of $\mathrm{BaWO}_{4}$. The flow chart to synthesize $\mathrm{BaWO}_{4}$ nanoparticles is indicated in Fig. 1. The main reaction which is taking place during the synthesis of $\mathrm{BaWO}_{4}$ nanoparticles is mentioned below:

$\mathrm{Ba}\left(\mathrm{NO}_{3}\right)_{2(\mathrm{~s})}+\mathrm{Na}_{2} \mathrm{WO}_{4(\mathrm{~s})} \rightarrow \mathrm{BaWO}_{4}+2 \mathrm{NaNO}_{3}$

Characterization

The crystallographic properties of $\mathrm{BaWO}_{4}$ were examined by X-ray diffraction (Shimadzu XRD6000) using $\mathrm{Cu} \mathrm{K \alpha}$ 


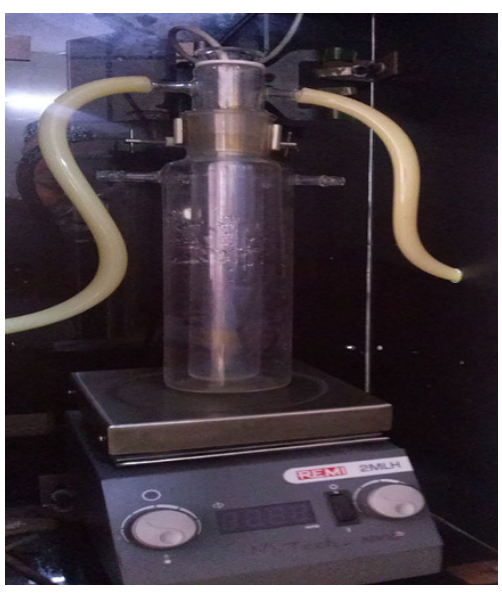

Fig. 2 Pyrex photo reactor equipped with the UV light

$(\lambda=0.154059 \mathrm{~nm})$ radiation with a nickel filter and a power of $40 \mathrm{kV} \times 30 \mathrm{~mA}$. The intensity data were collected at $25^{\circ} \mathrm{C}$ over a $2 \theta$ range of $10-90^{\circ}$ with a scan rate of $10^{\circ} \mathrm{min}^{-1}$. The FTIR spectra of the $\mathrm{BaWO}_{4}$ were examined by Fourier transform infrared spectrometer (Shimadzu spectrophotometer) using $\mathrm{KBr}$ pellet technique in the range from 2,000 to $400 \mathrm{~cm}^{-1}$ (spectral resolution was $4 \mathrm{~cm}^{-1}$ and number of scans was 20). The morphology, particle size and elemental compositions of the prepared material were studied by scanning electron microscope (SEM JEOL JSM-6610) equipped with an energy dispersive X-ray (EDAX) spectrophotometer and operated at $20 \mathrm{kV}$. Absorbance spectra of the catalyst were obtained by UV-Visible spectrophotometer (Shimadzu 1800). The samples were loaded into a quartz experimental set-up and the spectrum was recorded in the range 200-600 nm using absorbance method. The photoluminescence spectral analysis was examined by spectroflurometer (JASCO) at room temperature.

\section{Photocatalytic experiments}

The photocatalytic activity of $\mathrm{BaWO}_{4}$ nanoparticles was investigated in an aqueous solution of Rhodamine $\mathrm{B}$ as per the following procedure: The typical catalytic reactions were carried out at room temperature with $50 \mathrm{~mL}$ of an aqueous dye solution of Rhodamine B $(0.2 \mathrm{~g} / \mathrm{L})$ taken in a simple Pyrex photoreactor equipped with the $6 \mathrm{~W}$-UV light emitting source as indicated in the Fig. 2. To the above dye solution, $5 \mathrm{mg}$ of $\mathrm{BaWO}_{4}$ nanoparticles (as prepared sample, calcined at 400 and $800{ }^{\circ} \mathrm{C}$ ) were added individually and the mixture was allowed to react for about $30 \mathrm{~min}$ until they reach the level of equilibrium. After the given time interval, $2 \mathrm{~mL}$ of the solution was withdrawn from the Pyrex photoreactor and the UV-visible absorption spectrum was taken at $554 \mathrm{~nm}$ as indicated in the literature

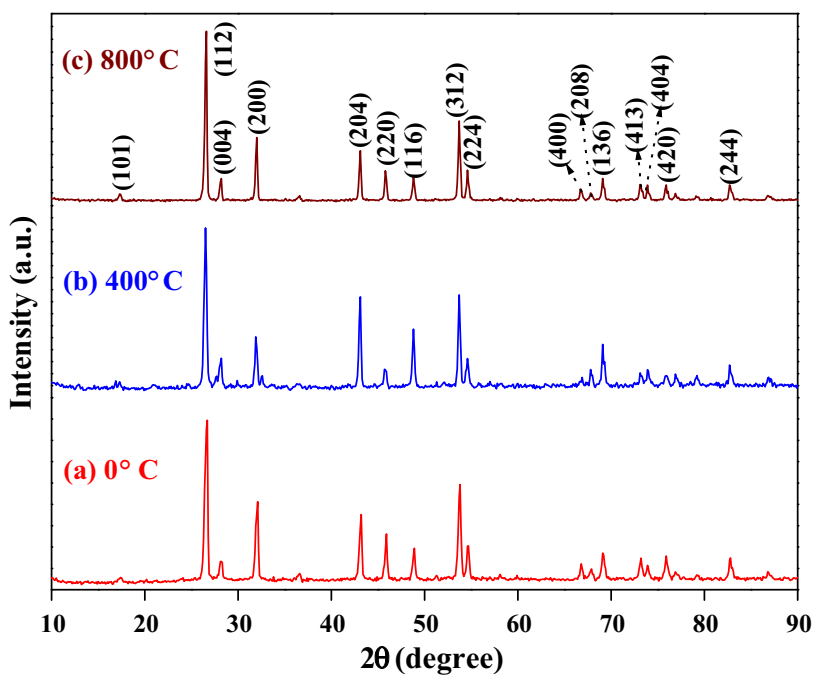

Fig. 3 XRD pattern of $\mathrm{BaWO}_{4}$ nanoparticles (a) $0{ }^{\circ} \mathrm{C}$ (as prepared), (b) calined at $400{ }^{\circ} \mathrm{C}$ and (c) calcined $800{ }^{\circ} \mathrm{C}$

[28]. The percentage of degradation of dye [29] was calculated with the following formula:

$\%$ of degradation of dye $=\left(C_{0}-C_{t} / \mathrm{C}_{0}\right) \times 100$

where, $C_{0}$ is the initial absorbance of the dye solution and $C_{t}$ is the absorbance at time interval, respectively.

\section{Results and discussion}

Characterization of $\mathrm{BaWO}_{4}$ nanoparticles

\section{$X$-ray diffraction}

Figure 3 shows the typical XRD patterns obtained on the $\mathrm{BaWO}_{4}$ nanoparticles (as prepared, calcined at 400 and $800{ }^{\circ} \mathrm{C}$ ). The XRD spectra of all the three samples were found to be uniform. The peak positions of each sample exhibit the tetragonal type structure of $\mathrm{BaWO}_{4}$ in comparison with the reported JCPDS card No. 85-0588. Further, no other impurity peak was observed in the XRD pattern. The crystalline sizes of all the samples were calculated using Scherrer [30] formula (which is mentioned below),

$\mathrm{D}=0.9 \lambda / \beta \cos \theta$

where, ' $\lambda$ ' is the wavelength of $\mathrm{X}$-ray radiation, ' $\beta$ ' is the full width at half maximum (FWHM) of the peaks at the diffracting angle $\theta$. The calculated crystalline sizes of each sample are presented in Table 1.

The theoretical [31] density $\left(D_{x}\right)$ values were calculated using the formula (4),

$D_{x}=(Z \times M) /\left(N \times a^{2} \times c\right) \mathrm{g} \mathrm{cm}^{-3}$ 
Table 1 The crystallographic parameters of the $\mathrm{BaWO}_{4}$ nanoparticles

\begin{tabular}{|c|c|c|c|c|c|}
\hline Sample & $\begin{array}{l}\text { Crystal } \\
\text { structure }\end{array}$ & $\begin{array}{l}\text { Unit cell lattice } \\
\text { parameter ' } a \text { and } c \text { ' }(\AA)\end{array}$ & $\begin{array}{l}\text { Unit cell } \\
\text { volume } \\
\left(\AA \AA^{3}\right)^{3}\end{array}$ & $\begin{array}{l}\text { Theoretical } \\
\text { density }(\mathrm{g} / \mathrm{cc})\end{array}$ & $\begin{array}{l}\text { Crystallite } \\
\text { size }(\mathrm{nm})\end{array}$ \\
\hline $\begin{array}{c}\mathrm{BaWO}_{4}(\mathrm{JCPDS} \\
\text { No. 85-0588) }\end{array}$ & $\begin{array}{l}\text { Tetragonal } \\
\text { body } \\
\text { centered }\end{array}$ & $\begin{array}{l}a=5.613 \\
c=12.720\end{array}$ & 400.81 & 6.383 & - \\
\hline $\begin{array}{l}\text { As prepared } \\
\text { sample }\end{array}$ & $\begin{array}{l}\text { Tetragonal } \\
\text { body } \\
\text { centered }\end{array}$ & $\begin{array}{l}a=5.590 \\
c=12.637\end{array}$ & 394.88 & 6.477 & 4.2592 \\
\hline $\begin{array}{l}\text { Calcined at } \\
400{ }^{\circ} \mathrm{C}\end{array}$ & $\begin{array}{l}\text { Tetragonal } \\
\text { body } \\
\text { centered }\end{array}$ & $\begin{array}{l}a=5.594 \\
c=12.657\end{array}$ & 396.07 & 6.459 & 4.922 \\
\hline $\begin{array}{l}\text { Calcined at } \\
800{ }^{\circ} \mathrm{C}\end{array}$ & $\begin{array}{l}\text { Tetragonal } \\
\text { body } \\
\text { centered }\end{array}$ & $\begin{array}{l}a=5.598 \\
c=12.687\end{array}$ & 397.58 & 6.434 & 5.1881 \\
\hline
\end{tabular}

where, ' $Z$ ' is the number of chemical species in the unit cell, ' $M$ ' is the molecular mass of the sample $(\mathrm{g} / \mathrm{mol}),{ }^{\prime} N$ ' is the Avogadro's number $\left(6.022 \times 10^{23}\right)$ and ' $a$ ' and ' $c$ ' are the lattice constants $(\mathrm{cm})$. The crystallographic parameters obtained on $\mathrm{BaWO}_{4}$ nanoparticles are indicated in Table 1 .

Fourier transform infrared spectroscopy

Figure 4 shows the FTIR transmittance spectra obtained on $\mathrm{BaWO}_{4}$ nanoparticles (as prepared, calcined at 400 and $800{ }^{\circ} \mathrm{C}$ ) and shows intense peaks at 1,525, 1,560, 1,590, $824,822,629,628,627,517,474$ and $438 \mathrm{~cm}^{-1}$. It is noted that the vibrations at $1,525-1,590 \mathrm{~cm}^{-1}$ are related to a $\mathrm{COO}$ stretching mode for a bidentate complex [32]. In addition, the spectrum displays a very broad absorption band from 1,000 to $400 \mathrm{~cm}^{-1}$. This band is attributed to the $\mathrm{M}-\mathrm{O}$ bonds, of a solid oxide network [32]. For $\mathrm{T}_{\mathrm{d}}$ symmetry, the vibrations for the $\left[\mathrm{WO}_{4}\right]^{2-}$ tetrahedral units [33] can be calculated as per the Eq. (5).

$T_{\mathrm{d}}=A_{1}\left(v_{1}\right)+E\left(v_{2}\right)+F_{2}\left(v_{3}\right)+F_{2}\left(v_{4}\right)$

In Eq. 9, all four vibrational modes are Raman active but only the $F_{2}\left(v_{3}\right)$ and $F_{2}\left(v_{4}\right)$ modes are IR active [34]. Therefore, a strong $\mathrm{W}-\mathrm{O}$ stretching in $\left[\mathrm{WO}_{4}\right]^{2-}$ tetrahedrons was detected at $822-824 \mathrm{~cm}^{-1}$. Also, a weak W-O bending was found in the range $438-629 \mathrm{~cm}^{-1}$ [35]. The obtained results are in accordance with the reported data.

Scanning electron microscopy

Figure 5 shows the SEM images of $\mathrm{BaWO}_{4}$ nanoparticles (as prepared, calcined at 400 and $800{ }^{\circ} \mathrm{C}$ ), which can also allow the estimation of the average particle size distribution of samples by counting approximately 200 particles using image tool software. The SEM results demonstrated the morphology of $\mathrm{BaWO}_{4}$ nanoparticles and this was strongly dependent on size of particles. Figure 5 a shows

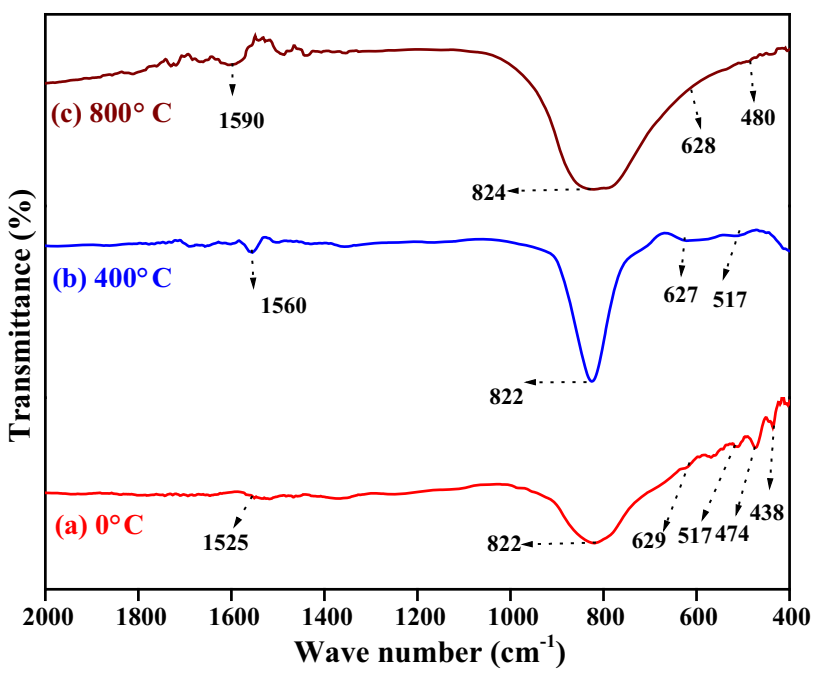

Fig. 4 FTIR transmittance spectrum of $\mathrm{BaWO}_{4}$ nanoparticles (a) $0^{\circ}$ $\mathrm{C}$ (as prepared), (b) calined at $400{ }^{\circ} \mathrm{C}$ and (c) calcined at $800{ }^{\circ} \mathrm{C}$

the SEM photograph of as-prepared $\mathrm{BaWO}_{4}$ nanoparticles, which have granular-like grains with sizes 700-800 nm. Figure $5 \mathrm{~b}$ shows the SEM photograph of calcined (at $400^{\circ}$ C) $\mathrm{BaWO}_{4}$ nanoparticles, which contain particles with grain sizes between $\sim 750$ and $850 \mathrm{~nm}$ range. Figure $5 \mathrm{c}$ shows the SEM photograph of calcined (at $800^{\circ} \mathrm{C}$ ) $\mathrm{BaWO}_{4}$ nanoparticles with grain sizes between $\sim 800$ and $900 \mathrm{~nm}$ range. All the SEM photographs show the presence of particles with less than $500 \mathrm{~nm}$ also in the samples. Considerably big particles present in the sample may be due to the agglomeration of particles at high temperature treatment [36].

\section{EDAX analysis}

Figure 6 shows the EDAX spectrum of $\mathrm{BaWO}_{4}$ nanoparticles. The presence of elements such as $\mathrm{Ba}, \mathrm{W}$ and $\mathrm{O}$ in the 

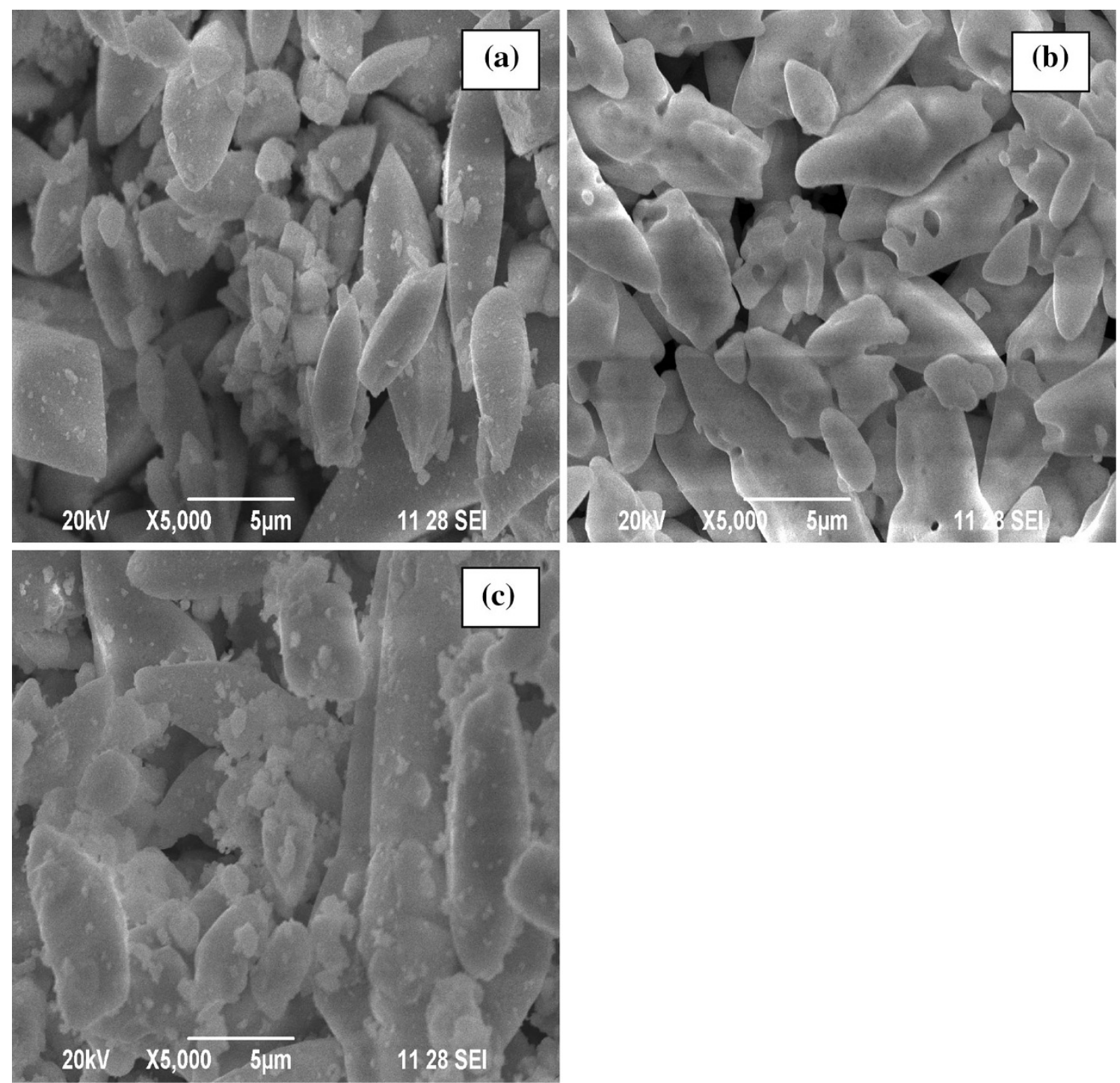

Fig. 5 SEM images of $\mathrm{BaWO}_{4}$ nanoparticles (a) $0{ }^{\circ} \mathrm{C}$ (as prepared), (b) calined at $400{ }^{\circ} \mathrm{C}$ and (c) calcined at $800{ }^{\circ} \mathrm{C}$

samples is confirmed by EDAX analysis. The atomic percentages of each element are given in Table 2. These results show the appropriate quantities of $\mathrm{Ba}, \mathrm{W}$ and $\mathrm{O}$ present in the samples.

\section{Optical properties}

Figure 7 shows the optical absorption spectrum obtained on $\mathrm{BaWO}_{4}$ nanoparticles (as prepared, calcined at 400 and $800{ }^{\circ} \mathrm{C}$ ). It was reported that absorption is a powerful, nondestructive technique to explore the optical properties of semiconducting nanoparticles [37]. The optical absorbance spectra for $\mathrm{BaWO}_{4}$ nanoparticles (as prepared, calcined at 400 and $800{ }^{\circ} \mathrm{C}$ ) appeared in the ultraviolet region: 274 , 272 and $271 \mathrm{~nm}$ (Fig. 7a, b, c). In order to calculate the direct band gap of the nanoparticles, Tauc [38] relationship is used in this research study as indicated in Eq. (6), $\alpha h v=A\left(h v-E_{\mathrm{g}}\right)^{1 / 2}$

where, ' $\alpha$ ' is the absorption coefficient, ' $A$ ' is a constant and $n=1 / 2$ for direct band gap semiconductor. An extrapolation of the linear region of a plot of $(\alpha h v)^{2}$ vs. $h v$ gives the value of the optical band gap $\left(E_{\mathrm{g}}\right)$ as shown in the inset of Fig. 8. The measured band gap was found to be 5.77, 5.82 and $5.88 \mathrm{eV}$ for $\mathrm{BaWO}_{4}$ nanoparticles, which is almost similar to the reported value of $5.78 \mathrm{eV}$ [32].

Photoluminescence properties

Figure 9 shows the PL spectrum of $\mathrm{BaWO}_{4}$ nanoparticles (as prepared, calcined at 400 and $800{ }^{\circ} \mathrm{C}$ ). The photoluminescence (PL) spectra for $\mathrm{BaWO}_{4}$ nanoparticles were studied at room temperature with the excitation wavelength of $350 \mathrm{~nm}$. The excitation wavelength was fixed based on 

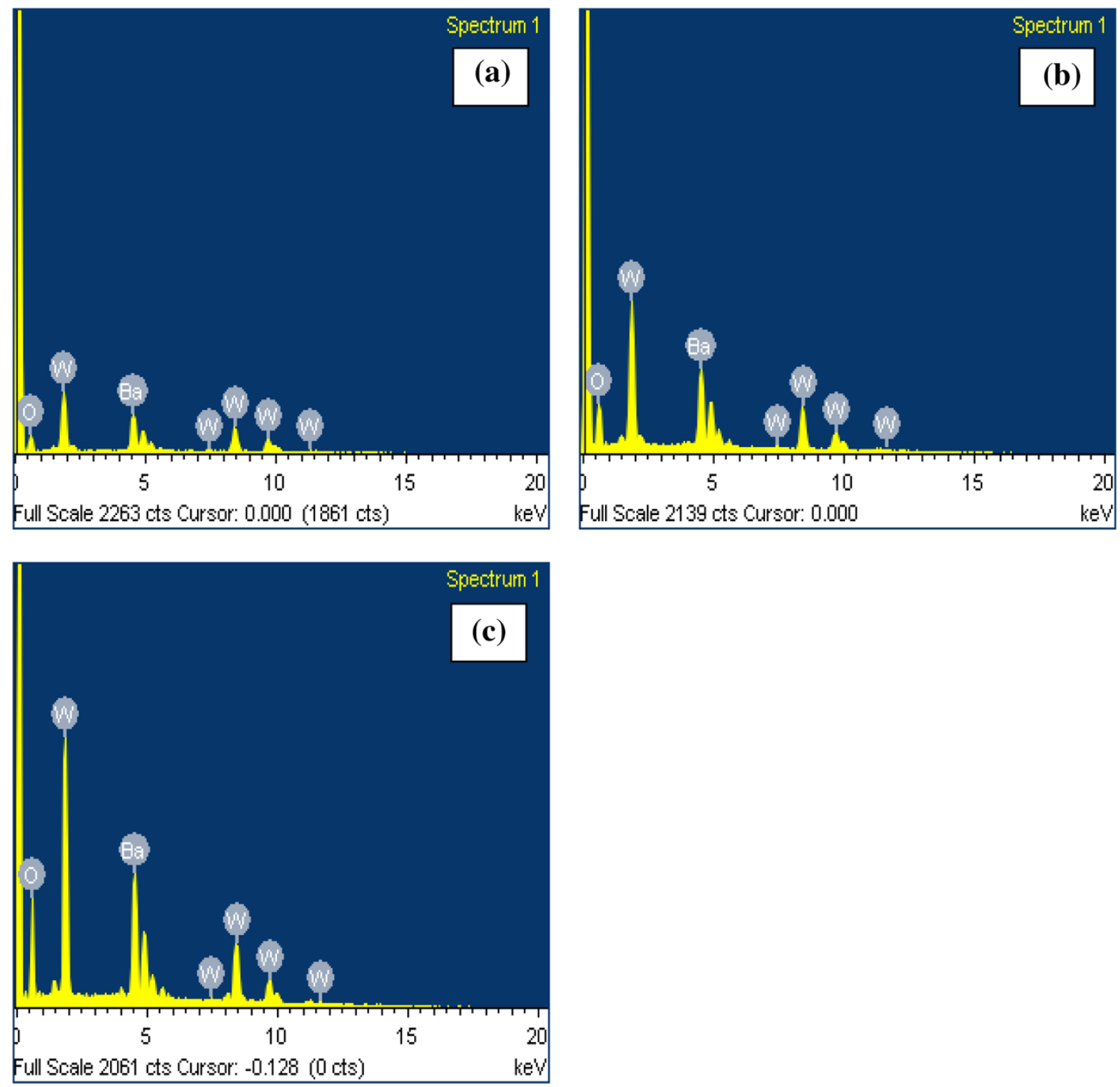

Fig. 6 EDAX spectrum of $\mathrm{BaWO}_{4}$ nanoparticles (a) $0{ }^{\circ} \mathrm{C}$ (as prepared), (b) calined at $400{ }^{\circ} \mathrm{C}$ and (c) calcined at $800{ }^{\circ} \mathrm{C}$

Table 2 The atomic weight percentage elemental composition of $\mathrm{BaWO}_{4}$ nanoparticles by EDAX analysis

\begin{tabular}{llll}
\hline Sample & \multicolumn{4}{l}{ Percentage of chemical composition } \\
\cline { 2 - 4 } & $\mathrm{Ba}$ & $\mathrm{W}$ & $\mathrm{O}$ \\
\hline As prepared & 20.22 & 15.16 & 64.62 \\
Calcined at $400{ }^{\circ} \mathrm{C}$ & 17.28 & 14.95 & 67.77 \\
Calcined at $800{ }^{\circ} \mathrm{C}$ & 16 & 14.67 & 69.34 \\
\hline
\end{tabular}

the result obtained from the UV studies. From the data, it was found that a strong board PL emission peak appeared at 545, 544 and $544 \mathrm{~nm}$ for the samples. From the reported data, the appearance of strong PL emission peak in the above range is attributable to the emission band at visible region of green emission [17] as found in the literature.
Also, the presence of broad peak is corresponding to the multilevel or multi-photon processes [39, 40]. As per the reported literature, the metal tungstates can exhibit blue PL spectra due to the charge transfer transition of the tetrahedral $\left[\mathrm{WO}_{4}\right]^{2-}$ group [41]. The emission peaks of $\mathrm{BaWO}_{4}$ nanoparticles may be responsible for blue shift in the PL spectra which may be due to the quantum size effect of the nanoparticles [42, 43].

\section{Photocatalytic properties}

Figure 10 shows the absorption spectrum of Rhodamine B in presence of $\mathrm{BaWO}_{4}$ nanoparticles (as prepared, calcined at 400 and $800{ }^{\circ} \mathrm{C}$ ). The catalytic activity of $\mathrm{BaWO}_{4}$ nanoparticles was investigated for the degradation of Rhodamine B present in water at room temperature using 


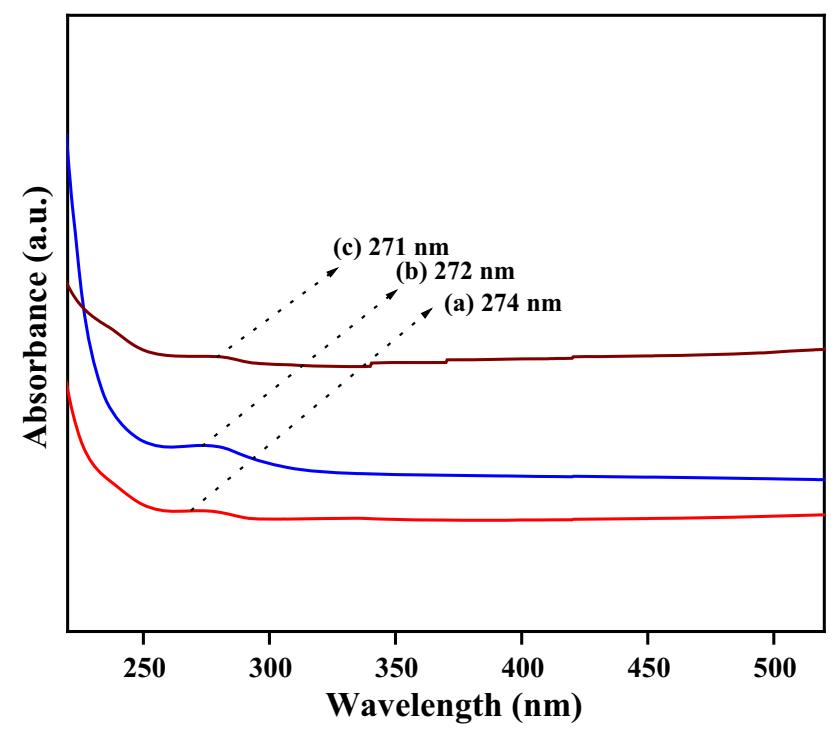

Fig. 7 Absorption spectrum of $\mathrm{BaWO}_{4}$ nanoparticles (a) $0{ }^{\circ} \mathrm{C}$ (as prepared), (b) calined at $400{ }^{\circ} \mathrm{C}$ and (c) calcined at $800{ }^{\circ} \mathrm{C}$

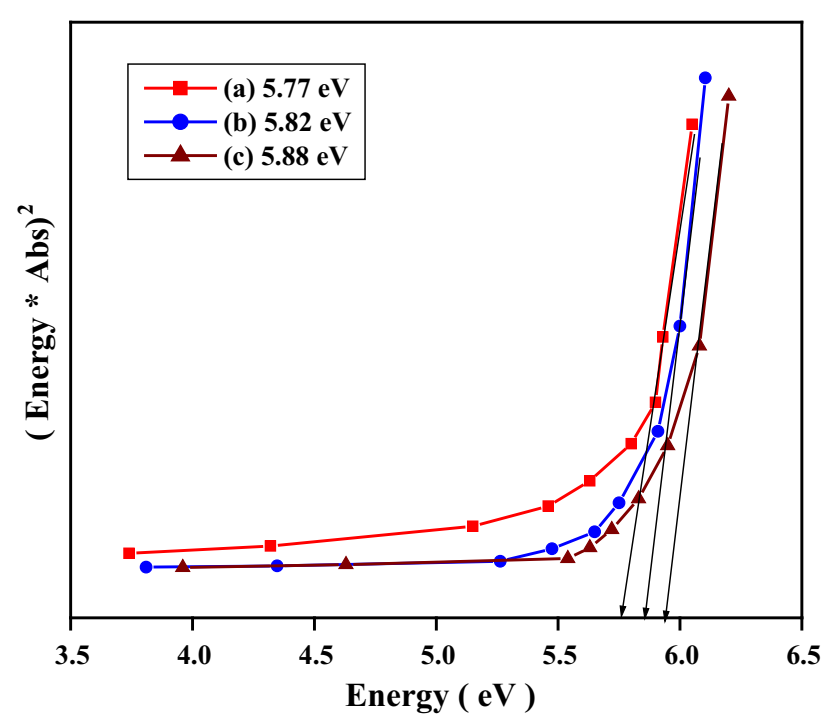

Fig. 8 Band gap spectrum of $\mathrm{BaWO}_{4}$ nanoparticles (a) $0{ }^{\circ} \mathrm{C}$ (as prepared), (b) calined at $400{ }^{\circ} \mathrm{C}$ and (c) calcined at $800{ }^{\circ} \mathrm{C}$

UV-visible spectroscopy. The chemical structure of Rhodamine B is shown in Fig. 11. The absorption wavelength was maintained at $554 \mathrm{~nm}$ throughout the study and the percentage of degradation of Rhodamine B was carefully monitored at various time intervals such as $0,30,60,90$, 120, 150 and 180 min, respectively. From Fig. 10, it was found that the sample without any catalyst degraded $37 \%$ of Rhodamine B present in water sample. However, the presence of catalysts (as prepared, calcined at $400{ }^{\circ} \mathrm{C}$ and calcined at $800^{\circ} \mathrm{C}$ ) degraded the Rhodamine B successfully ( $\sim 95,90$ and $88 \%$, respectively) after three hours of

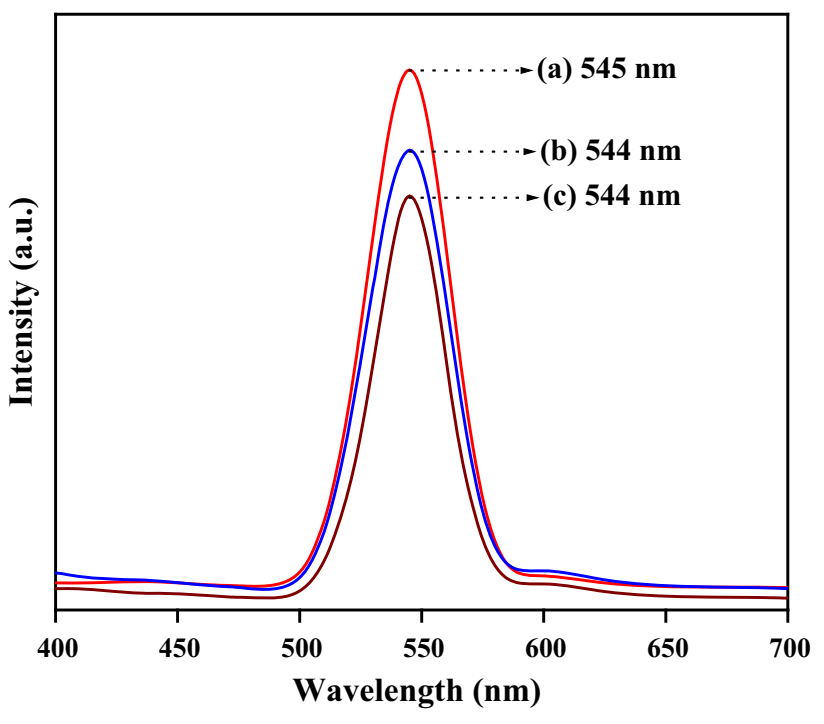

Fig. 9 PL spectrum of $\mathrm{BaWO}_{4}$ nanoparticles (a) $0{ }^{\circ} \mathrm{C}$ (as prepared), (b) calined at $400{ }^{\circ} \mathrm{C}$ and (c) calcined at $800^{\circ} \mathrm{C}$

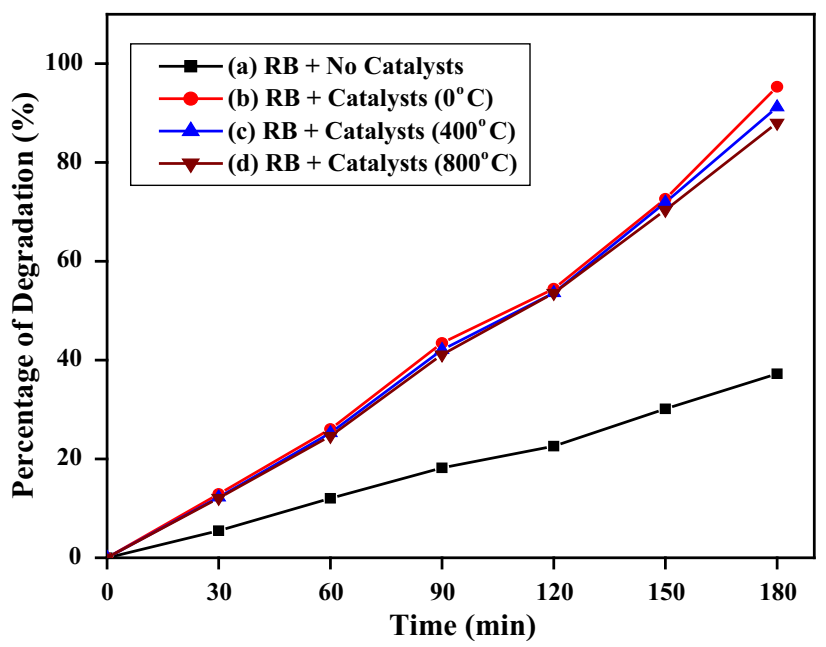

Fig. 10 Degradation spectrum of Rhodamine B in the presence of $\mathrm{BaWO}_{4}$ nanoparticles

exposure in presence of UV light at $554 \mathrm{~nm}$. This result demonstrates that as-prepared $\mathrm{BaWO}_{4}$ sample is more efficient to degrade Rhodamine $\mathrm{B}$ in presence of UV light.

A plot drawn between $\ln \left(C / C_{0}\right)$ versus Time is presented in Fig. 12 and it resembles the first-order kinetics curve as reported in the literature [44]. The degradation reactions of all $\mathrm{BaWO}_{4}$ nanoparticles with Rhodamine $\mathrm{B}$ dye exhibited pseudo first-order kinetics model with respect to the degradation time as indicated in the linear Eq. (7).

$\ln \left(C / C_{0}\right)=-k t$ 
<smiles>CCN(CC)c1ccc2c(-c3ccccc3C(=O)O)c3ccc(=[N+](CC)CC)cc-3oc2c1</smiles>

Fig. 11 Structure of Rhodamine B dye

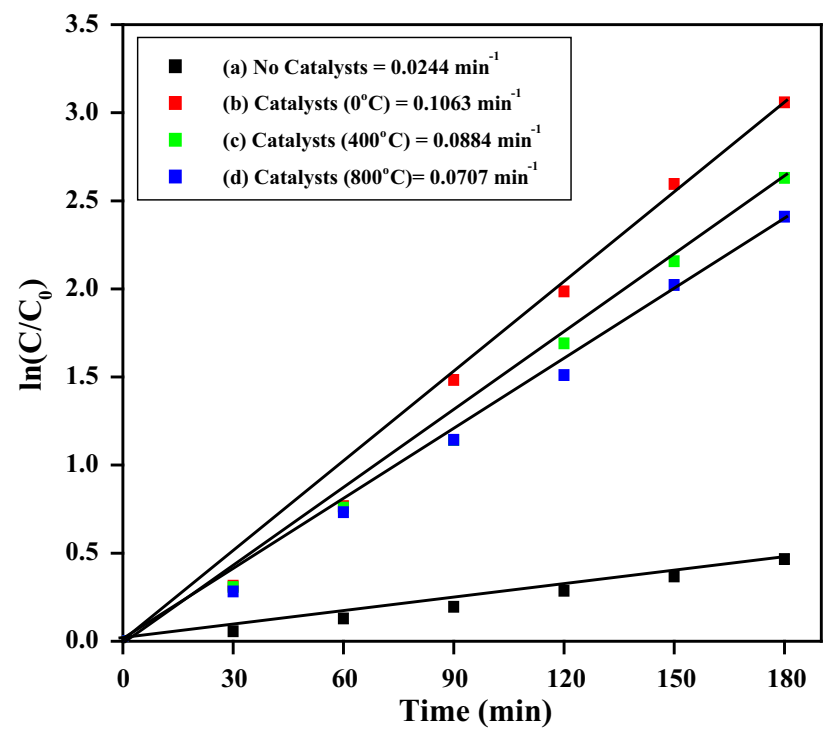

Fig. 12 First order kinetic plot of Rhodamine $\mathrm{B}$ dye using $\mathrm{BaWO}_{4}$ nanoparticles

where, ' $C_{0}$ is the initial concentration of dye and ' $C$ ' is the concentration at time ' $t$ ', ' $k$ ' is the reaction constant of the first-order reaction. The slope of the linear line gives the first-order rate constant. The rate constant values were found to be $0.0244 \mathrm{~min}^{-1}$ (absence of catalysts), $0.10629 \mathrm{~min}^{-1}$ (as prepared sample $\mathrm{BaWO}_{4}$ ), $0.0884 \mathrm{~min}^{-1}$ (sample heat-treated at $400{ }^{\circ} \mathrm{C}$ ) and $0.0707 \mathrm{~min}^{-1}$ (sample heat-treated at $800{ }^{\circ} \mathrm{C}$ ). From the result, it was found that the catalytic activity of asprepared $\mathrm{BaWO}_{4}$ nanoparticles is greater than that of samples heat treated at 400 and $800{ }^{\circ} \mathrm{C}$, respectively.

The photocatalytic mechanism suggested for the degradation of Rhodamine B dye present in water sample with $\mathrm{BaWO}_{4}$ nanoparticles in presence of UV light is indicated below [28, 45]:

Step 1: $h v+\mathrm{RB} \rightarrow \mathrm{RB}^{1}$ ( $\mathrm{RB}$ in singlet exited state)

Step 2: $\quad \mathrm{RB}^{1} \rightarrow \mathrm{RB}^{3}(\mathrm{RB}$ in triplet exited state) (ISC)
Step 3: $\quad h v+\mathrm{BaWO}_{4} \rightarrow \mathrm{h}_{(\mathrm{BaWO} 4)}^{+}+\mathrm{e}_{(\mathrm{BaWO} 4)}^{-}$

Step 4: $\mathrm{h}_{(\mathrm{BaWO} 4)}^{+}+\mathrm{OH}^{-} \rightarrow \mathrm{h}+\mathrm{OH}^{*}$

Step 5: $\mathrm{OH}^{*}+\mathrm{RB}^{3} \rightarrow$ Leuco form dye $\rightarrow$ degraded product

From the mechanism, it was found that reactions can be split into fragments.

In the first step, the Rhodamine B dye can absorb photons from light source and may be excited to singlet state. By losing some energy through inter-system crossing, the Rhodamine B dye can be converted into triplet state. On the other hand, $\mathrm{BaWO}_{4}$ absorbs photon, and one electron from its conduction band is transferred to valence band, generating a hole. This hole may be responsible for bleaching of Rhodamine B dye. This hole may abstract an electron from $\mathrm{OH}^{-}$ion and free radical $\mathrm{OH}^{*}$ is generated. This free radical abstracts an electron from conjugated and weaker site of the Rhodamine B dye. As a result Rhodamine B dye is broken down into fragments. Scavenger study has proved the participation of free radical in the reaction. Finally, various degraded products such as $\mathrm{NO}_{2}$, $\mathrm{CO}_{2}, \mathrm{H}_{2} \mathrm{O}$, etc. may take place in the process.

\section{Conclusion}

The $\mathrm{BaWO}_{4}$ nanoparticles were prepared by the simple, low-temperature route; furthermore, they were characterized by the XRD, FTIR, SEM, EDAX and UV-visible spectroscopy techniques. The XRD patterns show that the prepared samples are of tetragonal-type structure. No impurity phase has been observed in XRD. FTIR spectra confirmed the presence of $\mathrm{M}-\mathrm{O}$ bond in the product. The SEM studies confirmed the presence of granular-like grains in the samples. The EDAX data confirmed the presence of corresponding elements in the samples. The band gap data obtained on the sample based on absorbance spectra studies are similar to the reported data. It was found that among the samples studied, the as-prepared $\mathrm{BaWO}_{4}$ is more effective in degrading the Rhodamine $\mathrm{B}$ dye present in the water sample in presence of UV light at the wave length of $554 \mathrm{~nm}$ at normal room temperature. Hence, $\mathrm{BaWO}_{4}$ nanoparticles are suggested as a potential candidate to remove organic pollutants present in water by simple photocatalysis at room temperature.

Author contribution ASN has guided MMJS to carry out this research study. MMJS has carried out the experiments and he has written the raw manuscript. ASN has edited and refined the manuscript towards publication. Both authors have read and approved the final manuscript. 
Acknowledgments The authors are grateful to the DST Nano Mission, Government of India, New Delhi, for its financial assistance to carry out the research work. The authors are also thankful to the management of Karunya University for their support and encouragement to carry out and publish this research work.

Conflict of interest The authors declare that they have no conflict of interest.

Open Access This article is distributed under the terms of the Creative Commons Attribution License which permits any use, distribution, and reproduction in any medium, provided the original author(s) and the source are credited.

\section{References}

1. Ameta, Ankita, Ameta, Rakshit, Ahuja, Mamta: Photocatalytic degradation of methylene blue over ferric tungstate. Sci. Revs. Chem Commun 3, 172-180 (2013)

2. Vinu, R., Madras, G.: Kinetics of sonophotocatalytic degradation of anionic dyes with Nano- $\mathrm{TiO}_{2}$. Environ. Sci. Technol 43, 473-479 (2009)

3. Mahanta, D., Madras, G., Radhakrishnan, S., Patil, S.: Adsorption of sulfonated dyes by polyaniline emeraldine salt and its kinetics. J. Phys. Chem. B 112, 10153-10157 (2008)

4. Dafnopatidou, E.K., Gallios, G.P., Tsatsaroni, E.G., Lazaridos, N.K.: Reactive dyestuffs removal from aqueous solutions by flotation. Ind. Eng. Chem. Res 46, 2125-2132 (2007)

5. Marin, M.L., Santos-Juanes, L., Arques, A., Amat, A.M., Miranda, M.A.: Organic photocatalysts for the oxidation of pollutants and model compounds. Chem. Rev 112, 1710-1750 (2012)

6. Manjon, F.J., Errandonea, D., Garro, N., Pellicer-Porres, J., Rodriguez-Hernandez, P., Radescu, S., Lopez-Solano, J., Mujica, A., Munoz, A.: Lattice dynamics of sheelite tungstates under high pressure I. BaWO . Physical Rev. B. 74, 144111-144117 (2006)

7. Sinelnikov, B.M., Sokolenko, E.V., Zvekov, V.Y.: The Nature of green luminescence centers in scheelite. Inorg. Mater 32, 999-1001 (1996)

8. Yang, P.G., Liu, J., Yang, H., Yu, X., Guo, Y., Zhou, Y., Liu, J.: Synthesis and characterization of new red phosphors for white LED applications. J. Mater. Chem 19, 3771-3774 (2009)

9. Tamaki, J., Fujii, T., Fujimori, K., Miura, N., Yamazoe, N.: Application of metal tungstate-carbonate composite to nitrogen oxides sensor operative at elevated temperature. Sens. Actuators B 24(25), 396-399 (1995)

10. Balakshy, V.I., Asratyan, K.R., Molchanov, V.Y.: Acousto-optic collinear diffraction of a strongly divergent optical beam. J. Opt. A: Pure Appl. Opt 3, S87-S92 (2001)

11. Veresnikova, A.V., Lubsandorzhiev, B.K., Barabanov, I.R., Grabmayr, P., Greiner, D., Jochum, J., Knapp, M., Ostwald, C., Poleshuk, R.V., Ritter, F., Shaibonov, B.A.M., Vyatchin, Y.E., Meierhofer, G.: Fast scintillation light from $\mathrm{CaMoO}_{4}$ crystals. Nucl. Instrum. Methods Phys. Res. Sect. A. 603, 529-531 (2009)

12. Vidya, S., Sam Solomon, Thomas, J.K.: Synthesis, characterization, and low temperature sintering of nanostructured $\mathrm{BaWO}_{4}$ for optical and LTCC applications. Adv. Condensed Matt. Phy. 409620, 1-11 (2013)

13. Choi, G.K., Kim, J.R., Yoon, S.H., Hong, K.S.: Microwave dielectric properties of scheelite $(\mathrm{A}=\mathrm{Ca}, \mathrm{Sr}, \mathrm{Ba})$ and wolframite $(\mathrm{A}=\mathrm{Mg}, \mathrm{Zn}, \mathrm{Mn}) \mathrm{AMoO}_{4}$ compounds. J. Eur. Ceram. Soc 27(8-9), 3063-3067 (2007)

14. Liao, J., Qiu, B., Wen, H., Chen, J., You, W., Liu, L.: Synthesis process and luminescence properties of $\mathrm{Tm}^{3+}$ in $\mathrm{AWO}_{4}(\mathrm{~A}=\mathrm{Ca}$,
Sr, Ba) blue phosphors. J. Alloys Compds 487(1-2), 758-762 (2009)

15. Fan, L., Fan, Y.X., Duan, Y.H., Wang, Q., Wang, H.T., Jia, G.H., Tu, C.Y.: Continuous-wave intracavity Raman laser at $1179.5 \mathrm{~nm}$ with SrWO4 Raman crystal in diode-end-pumped Nd:YVO4 laser. Appl. Phys. B-Lasers Optics. 94(4), 553-557 (2009)

16. Ivleva, L.I., Voronina, I.S., Lykov, P.A., Berezovskaya, L.Y., Osiko, V.V.: Growth of optically homogeneous BaWO4 single crystals for Raman lasers. J. Cryst. Growth 304(1), 108-113 (2007)

17. Cavalcante, L.S., Sczancoski, J.C., Lima Jr, L.F., Espinosa, J.W.M., Pizan, iPS, Varela, J.A., Longo, E.: Synthesis, characterization, anisotropic growth and photoluminescence of BaWO4. Cryst. Growth Des 9(2), 1002-1012 (2009)

18. Siriwong, P., Thongtem, T., Phuruangrat, A., Thongtem, S.: Hydrothermal synthesis, characterization, and optical properties of wolframite $\mathrm{ZnWO}_{4}$ nanorods. Cryst. Eng. Comm 13, 1564-1569 (2011)

19. Shi, S., Liu, X., Gao, J., Zhou, J.: Spectroscopic properties and intense redlight emission of $(\mathrm{Ca}, \mathrm{Eu}, \mathrm{M}) \mathrm{WO} 4(\mathrm{M}=\mathrm{Mg}, \mathrm{Zn}, \mathrm{Li})$. Spectrochimica Acta Part A 69, 396-399 (2008)

20. Huang, J.Y., Jia, Q.X.: Structural properties of SrWO4 films synthesized by pulsed-laser deposition. Thin Solid Films 444, 95-98 (2003)

21. Chen, L., Gao, Y., Zhu, J.: Luminescent properties of $\mathrm{BaWO}_{4}$ films prepared by cell electrochemical technique. Mater. Lett 62 , 3434-3436 (2008)

22. Afanasiev, P.: Molten salt synthesis of barium molybdate and tungstate microcrystals. Mater. Lett 61, 4622-4626 (2007)

23. Lima, R.C., Anicete-Santos, M., Orhan, E., Maurera, M.A.M.A., Souza, A.G., Pizani, P.S., Leite, E.R., Varela, J.A., Longo, E.J.: Photoluminescent property of mechanically milled $\mathrm{BaWO}_{4}$ powder. J. Luminescence 126, 741-746 (2007)

24. Zhang, C., Shen, E., Wang, E., Kang, Z., Gao, L., Hu, C., Xu, L.: One-step solvothermal synthesis of high ordered $\mathrm{BaWO}_{4}$ and $\mathrm{BaMoO}_{4}$ nanostructures. Mater. Chem. Phys 96, 240-243 (2006)

25. Thongtem, T., Phuruangrat, A., Thongtem, S.: Characterization of $\mathrm{MeWO}_{4}(\mathrm{Me}=\mathrm{Ba}, \mathrm{Sr}$ and $\mathrm{Ca})$ nanocrystallines prepared by sonochemical method. Appl. Surf. Sci 254, 7581-7585 (2008)

26. Na L., Faming G., Li H., Dawei G.: DNA-Templated Rational Assembly of $\mathrm{BaWO}_{4}$ Nano Pair-Linear Arrays, J. Phys. Chem. C.114, 16114-16121 (2010)

27. Lee, Heon: Sung Hoon Park, Young-Kwon Park, Byung Hoon Kim, Sun-Jae Kim, Sang-Chul Jung: rapid destruction of the rhodamine $\mathrm{B}$ using $\mathrm{TiO}_{2}$ photocatalyst in the liquid phase plasma. Chem. Central J 7(1), 156 (2013)

28. Wilhelm, Patrick, Stephan, Dietmar: Photodegradation of rhodamine B in aqueous solution via $\mathrm{SiO}_{2} @ \mathrm{TiO}_{2}$ nano-sphere. J. Photochem Photobiol A Chem 185, 19-25 (2007)

29. Mohamed, R.M., Baeissa, E.S., Mkhalid, I.A., Al-Rayyani, M.A.: Optimization of preparation conditions of $\mathrm{ZnO}-\mathrm{SiO}_{2}$ xerogel by sol-gel technique for photodegradation of methylene blue dye. Appl. Nanosci 3, 57-63 (2013)

30. Cullity, B.D.: Elements of X-ray diffraction 2nd Ed. AddisonWesley Publishing Company Inc.: (1978)

31. Rao, C.N.R.: Chemical applications of infrared spectroscopy. Academic Press, New York (1963)

32. Pontes, F.M., Maurera, M.A.M.A., Souza, A.G., Longo, E., Leite, E.R., Magnani, R., Machado, M.A.C., Pizani, P.S., Varela, J.A.: Preparation, structural and optical characterization of $\mathrm{BaWO}_{4}$ and $\mathrm{PbWO}_{4}$ thin films prepared by a chemical route. J. Eur. Ceram. Soc 23, 3001-3007 (2003)

33. Phuruangrat, A., Thongtem, T., Thongtem, S.: Analysis of lead molybdate and lead tungstate synthesized by a sonochemical method. Curr. Appl. Phys 10, 342-345 (2010) 
34. Burcham, L.J., Wachs, I.E.: Vibrational analysis of the two nonequivalent, tetrahedral tungstate $\left(\mathrm{WO}_{4}\right)$ units in $\mathrm{Ce}_{2}\left(\mathrm{WO}_{4}\right)_{3}$ and $\mathrm{La}_{2}\left(\mathrm{WO}_{4}\right)_{3}$. Spect. Acta Part A 54, 1355-1368 (1998)

35. Phuruangrat, Anukorn, Thongtem, Titipun, Thongtem, Somchai: Characterization of starfruit-like $\mathrm{PbWO}_{4}$ microstructured clusters synthesized by a solution route. J. Ceram. Process. Res 13(5), 514-516 (2012)

36. Gulino, Dapporto, P., Rossi, P., Fragala, I.: A novel self-liquid MOCVD precursor for $\mathrm{Co}_{3} \mathrm{O}_{4}$ thin films. Chem. Mater 15, 3748-3752 (2003)

37. Faisal, M., Sher Bahadar Khan, Mohammed, M.R., Aslam, J., Kalsoom, A., Abdullah, M.M.: Role of $\mathrm{ZnO}-\mathrm{CeO}_{2}$ nanostructures as a photo-catalyst and chemi-sensor. J. Mater. Sci. Technol 27, 594-600 (2011)

38. Cimino, A., Lo Jacono, M., Schiavello, M.: Structural, magnetic, and optical properties of nickel oxide supported on ßeta.- and $\gamma$ gamma-aluminas. J. Phys. Chem 75, 1044-1050 (1971)

39. Yin, Yongkui, Gan, Zibao, Sun, Yuzeng, Baibin Zhou, Xu, Zhang, Dawei Zhang, Gao, Peng: Controlled synthesis and photoluminescence properties of $\mathrm{BaXO}_{4}(\mathrm{X}=\mathrm{W}$, Mo) hierarchical nanostructures via a facile solution route. Mater. Lett 64, 789-792 (2010)

40. Wang, R., Liu, C., Zeng, J., Li, K.W., Wang, H.: Fabrication and morphology control of $\mathrm{BaWO}_{4}$ thin films by microwave assisted chemical bath deposition. J. Solid State Chem 182, 677-684 (2009)

41. Blasse, G.: Classical phosphors: a Pandora's box. J. Luminescence 72-74, 129-134 (1997)

42. Thresiamma, G., Sunny, J., Sunny, A.T., Suresh, M.: Fascinating morphologies of lead tungstate nanostructures by chimie douce approach. J. Nanopart. Res 10, 567-575 (2008)

43. Shen, Y., Li, W., Li, T.: Microwave-assisted synthesis of $\mathrm{BaWO}_{4}$ nanoparticles and its photoluminescence properties. Mater. Lett 65, 2956-2958 (2011)

44. Asir, A.M., Al-Amoudi, M.S., Al-Talhi, T.A., Al-Talhi, A.D.: Photodegradation of rhodamine $6 \mathrm{G}$ and phenol red by nanosized $\mathrm{TiO}_{2}$ under solar irradiation. J. Saudi Chem. Soc 15, 121-128 (2011)

45. Mills, A., Davies, R.H., Worsley, D.: Water purification by semiconductor photocatalysis. Chem. Soc. Reviews 1993(22), 417-425 (1993) 